\title{
Optimization of Photo-Hydrogen Production by Immobilized Rhodopseudomonas Faecalis RLD-53
}

\author{
Bing-Feng Liu, Guo-Jun Xie, Wan-Qian Guo, Jie Ding, Nan-Qi Ren \\ State Key Laboratory of Urban Water Resource and Environment, Harbin Institute of Technology, Harbin, China \\ E-mail: rnq@hit.edu.cn; jianfeibio@yahoo.com.cn
}

Received December $7^{\text {th }}, 2010$; revised January $10^{\text {th }}, 2011$; accepted January $17^{\text {th }}, 2011$

\begin{abstract}
In this work, the optimization of hydrogen production by photo-fermentation bacteria immobilized on agar gel granule was systematic investigated in batch culture. Experiment focus on the effect of some important affecting factors on photo-hydrogen production. Results indicated that immobilized Rhodopseudomonas faecalis RLD-53 exhibited the highest hydrogen yield of $3.15 \mathrm{~mol} \mathrm{H}_{2} / \mathrm{mol}$ acetate under follow optimal condition: agar granule diameter of $2.5 \mathrm{~mm}$, inoculum age of $24 \mathrm{~h}$, agar concentration of $2 \%$, biomass of $4 \mathrm{mg} / \mathrm{ml}$ in agar and light intensity of 9000 lux. More importantly, immobilized photo-fermentation bacteria not only can enhance hydrogen production but can increase acids-tolerance capacity, even at pH 5.0 hydrogen also was produced, and thus hopefully immobilized photo-fermentation bacteria can be applied in the combination of dark and photo-fermentation for hydrogen production with high yield.
\end{abstract}

Keywords: Hydrogen Production, Photo-Fermentation, Agar Gel, Immobilized Rhodopseudomonas Faecalis, Acids-Tolerance Capacity

\section{Introduction}

The shortage of fossil fuels, the pollution of global environment and emissions of greenhouse gas are attracting more and more attention of researches. But, up to now, the major source of energy is still supplied from fossil fuels. Hence, we urgent need to develop new and renewable energy to replace fossil fuels. Bio-hydrogen is a clean, environmental friendly and recycle energy carrier and recognized as a promising substitute of fossil fuels in future. At present, two main pathways, dark and photo-fermentation, were used for bio-hydrogen production [1]. Recently, bio-hydrogen production by photofermentation has exhibited great potential. In particular dark-fermentation process produced short chain acids, which can be utilizing by photo-fermentation process for additional hydrogen production. Thus, the combination of dark and photo fermentation for hydrogen production can achieve a high overall hydrogen yield, which hopefully close to theoretically maximum value of $12 \mathrm{~mol}$ $\mathrm{H}_{2} / \mathrm{mol}$ hexose. The overall hydrogen yield of $13.7 \mathrm{~mol}$ $\mathrm{H}_{2} /$ mol-sucrose (equivalent to $6.85 \mathrm{~mol} \mathrm{H}_{2} /$ mol hexose) was obtained using sequential dark and photo-fer mentation from beet molasses [2]. Previous our work showed that the two-step of dark and photo fermentation reached a nice hydrogen yield of 6.32 [3] and 5.37 [4] mol $\mathrm{H}_{2} /$ mol glucose in batch experiment. Other some reports also demonstrated that the total hydrogen yield of sequential dark and photo-fermentation was obviously higher than that of a single dark fermentation process using single substrate as sole carbon source [5-8].

The immobilization technology for dark fermentation hydrogen production has been widely studied $[9,10]$. Usually, bacteria main were immobilized on carrier such as polyacrylamide [11], polyvinyl alcohol [12], or agar gel [13], etc. Nearly all their work showed that immobilized dark fermentative bacteria can enhance and stabilize hydrogen production process. There are only a few reports about the immobilization of photo-fermentation bacteria for improving the bio-hydrogen process $[14,15]$. However, these reports have not focused on the optimization of immobilized condition.

Therefore, in this study photo-fermentation bacteria were immobilized on agar gel granule to explore their hydrogen production capacity. The some key immobilized parameters, for example, agar granule diameter, inoculum age, agar concentration, $\mathrm{pH}$, biomass in agar and light intensity, were systematic optimized for improving photo-hydrogen production by batch culture.

\section{Method}

\subsection{Bacterial Strain and Medium}

Photo-fermentative bacterium Rhodopseudomonas fae- 
calis strain RLD-53, the previously isolated from fresh water pond, used in this study [16]. The medium for growth and hydrogen production was same with previous description by Liu et al. [17]. Acetate of $50 \mathrm{mmol} / \mathrm{l}$ was used as sole carbon source in medium for hydrogen production. The strain RLD-53 was pre-cultured at $35^{\circ} \mathrm{C}$ for $24 \mathrm{~h}$ under light intensity of 2000 lux with incandescent lamps $(60 \mathrm{~W})$ and argon was used to maintain anaerobic condition.

\subsection{Hydrogen Production Procedure}

The experiment was carried out in $100 \mathrm{ml}$ serum bottles, which were sealed by rubber plugs and filled with argon to maintain anaerobic conditions. $80 \mathrm{ml}$ medium for hydrogen production was put into reaction bottles. The bottles with liquid medium were sterilized at $121^{\circ} \mathrm{C}$ for 15 min. Operation parameters were as follows: inoculant age of $24 \mathrm{~h}, \mathrm{OD}_{660}$ of 1.68 , inoculant volume of $10 \%$ $(\mathrm{v} / \mathrm{v})$, the bottles were shaken on the constant temperature incubation oscillator at $120 \mathrm{rpm}$, culture temperature of $35^{\circ} \mathrm{C}$, The light intensity of outside surface of the bottles was maintained at 4000 lux by a incandescent lamps of $60 \mathrm{~W}$.

\subsection{Preparation of Immobilized Cell}

The cells of photo-fermentation bacteria were harvested by centrifugation at $6000 \mathrm{rpm}$ for $10 \mathrm{~min}$. Agar was dissolved in $20 \mathrm{ml}$ of sterile water at $0.4 \%(\mathrm{w} / \mathrm{v})$ and incubated at $100^{\circ} \mathrm{C}$, and then it was used for the immobilization of bacterial cells. Agar solution was cooled to 40-50 ${ }^{\circ} \mathrm{C}$ and mixed with $20 \mathrm{ml}$ prepared suspension of centrifuged $R$. faecalis RLD-53 in a beaker. The above mixture was immediately inhaled into a syringe of $50 \mathrm{ml}$ by hand and until agar gel was formed, and then agar gel of containing bacterial cells was injected into the medium through a syringe. The dry weight of the bacterial cells in the each agar gel granule with the average diameter of about $2.5 \mathrm{~mm}$ was approximately $0.113 \mathrm{mg}$.

\subsection{Analytical Method}

Hydrogen analysis in evolved gas was performed using a gas chromatograph (GC) (Model SC-II, Shanghai Analysis Instrument Factory) equipped with a thermal conductivity detector and a 2-m stainless column packed with 5 $\AA$ molecular sieves. The operational temperatures at the injection port, the column oven and detector were 100, 60 and $105{ }^{\circ} \mathrm{C}$, respectively. Argon was used as carrier gas at a flow rate of $70 \mathrm{ml} / \mathrm{min}$. The volatile fatty acids in supernatant of culture broth were determined using a second GC (Model GC122, Shanghai Analysis Instrument Factory) equipped with a flame ionization detector and a $30 \mathrm{~m} \times 0.25 \mathrm{~mm} \times 0.25 \mathrm{~mm}$ fused-silica capillary column. The liquor samples were first centrifuged at
12,000 rpm for $5 \mathrm{~min}$, and then acidified with hydrochloric acid and filtered through a $0.2-\mu \mathrm{m}$ membrane before free acids were analyzed. Nitrogen was used as carrier gas.

The light intensity (lux) was measured by using a digital luxmeter (TES1330A, Junkai Co.). Cell concentration was determined by an Amersham Pharmacia Biotech ultraspec $34300 \mathrm{UV} / \mathrm{V}$ is spectrophotometer.

\section{Results and Discussion}

\subsection{The Effect of Agar Gel Granule Size}

Agar granule size was an important factor affecting hydrogen production by photo-fermentation. Agar granule size of $0.5 \mathrm{~mm}, 1 \mathrm{~mm}, 1.5 \mathrm{~mm}, 2.5 \mathrm{~mm}$ made by different sizes of syringe. Acetate of $50 \mathrm{mmol} / \mathrm{l}$, glutamate of $10 \mathrm{mmol} / \mathrm{l}$, reaction system of $80 \mathrm{ml}$, incubation temperature of $35^{\circ} \mathrm{C}$ and light intensity of 4000 lux were used.

Hydrogen production increased gradually with the increase of agar granule size from $0.5-2.5 \mathrm{~mm}$ (Figure 1). Agar granule size at $0.5,1.0,1.5$ and $2.5 \mathrm{~mm}$, cumulative volume of hydrogen was $170,210,240$ and $270 \mathrm{ml} / \mathrm{re}-$ actor, respectively, and the control was $218 \mathrm{ml} /$ reactor. This result indicated that hydrogen yield was higher compared to other size when agar granule size was at 1.5 and $2.5 \mathrm{~mm}$. Agar granule size at $2.5 \mathrm{~mm}$, hydrogen yield reached maximum value of $3.15 \mathrm{~mol} \mathrm{H}_{2} / \mathrm{mol}$ acetate, conversion efficiency of substrate was $78.75 \%$ and hydrogen content was between $75 \%-85 \%$. In addition, immobilized bacterial cells can lengthen the time of hydrogen production. Hydrogen production of non-immobilized cell stopped at $192 \mathrm{~h}$, but hydrogen production of immobilized cell stopped at $264 \mathrm{~h}$. The utilization efficiency of substrate of immobilized cell

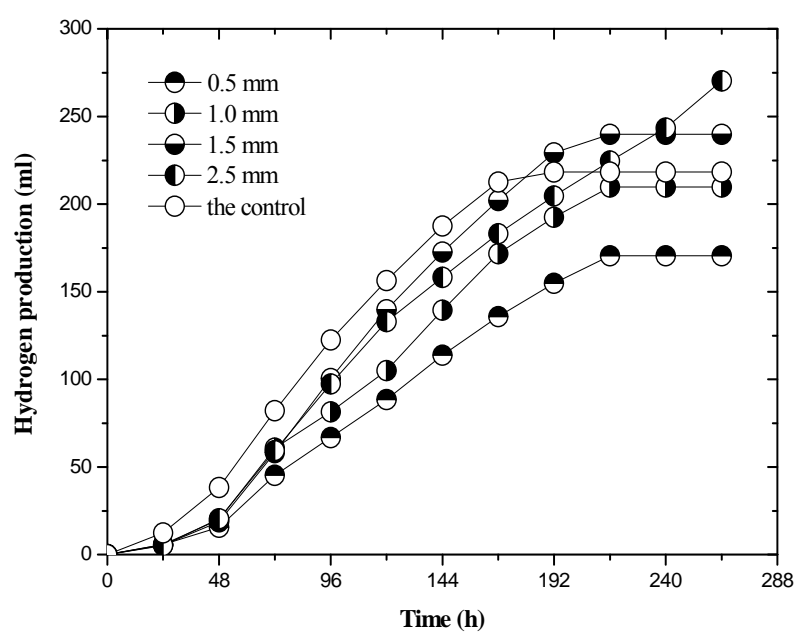

Figure 1. The effect of gel granule size on photo- $\mathrm{H}_{2}$ Production. 
was higher compared to non-immobilized cell. Within 48 $\mathrm{h}$ of culture, a great quantity of substrate was consumed for cell growth and the utilization efficiency of substrate was $0.04 \mathrm{~g}$ acetate $/ \mathrm{l} / \mathrm{h}$. However, the utilization efficiency of substrate of immobilized cell was $0.018 \mathrm{~g}$ acetate $/ \mathrm{l} / \mathrm{h}$, more acetate was for hydrogen production (Figure 2). These seem to imply that the bacteria were immobilized in agar gel can limit substrate for itself growth and increase hydrogen production, and lengthen the time of hydrogen production. So, agar granule size of $2.5 \mathrm{~mm}$ was used follow experiment for further research.

\subsection{The Effect of Inoculant Age}

In this test, the inoculant age of $12,24,36,48,60,72,84$ and $96 \mathrm{~h}$ was employed to explore their hydrogen production capacity.

The difference in hydrogen production under various inoculant ages is very obviously (Figure 3). Higher yield and production rate of hydrogen was obtained when inoculant age was $24 \mathrm{~h}$ and $72 \mathrm{~h}$, and cumulative volume of hydrogen was $246 \mathrm{ml} /$ reactor and $233 \mathrm{ml} /$ reactor, respectively. Inoculant age was at 12, 48 and $84 \mathrm{~h}$, the yield and production rate of hydrogen was similarly and it was about $200 \mathrm{ml} /$ reactor. Inoculant age at 36 and $96 \mathrm{~h}$, cumulative volume of hydrogen was about $160 \mathrm{ml} / \mathrm{re}-$ actor. However, inoculant age at $60 \mathrm{~h}$, hydrogen yield only was about $100 \mathrm{ml} /$ reactor. The hydrogen production by the bacteria cause the results of differences may be related to physiological state and enzymes activity of bacteria. We think that a long time of bacteria in the agar, nitrogenase activity was restored or enhanced leading to the hydrogen yield in high level. Inoculant age has a direct impact on the cell's physiological state and the chemical components of culture. Our result was consistent with Felten et al.'s report, which showed that the

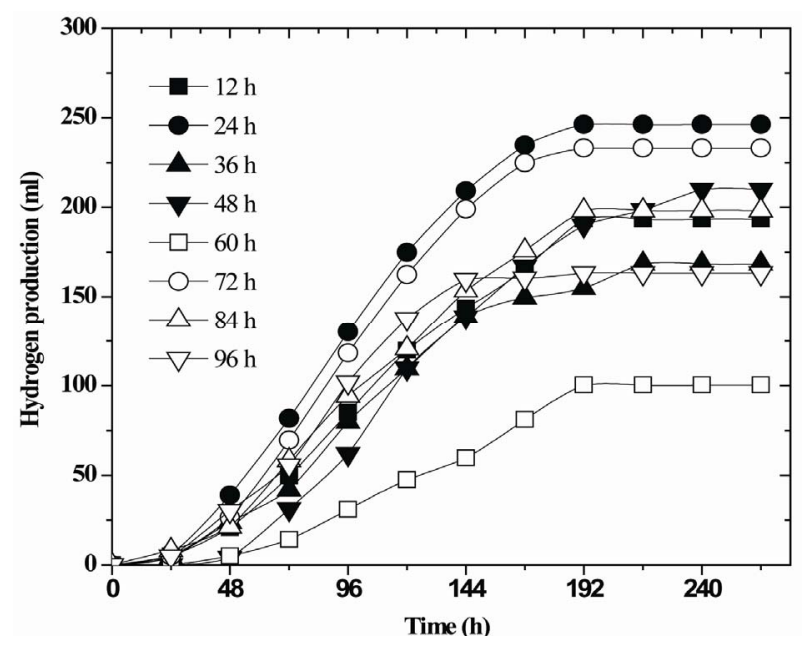

Figure 2. The consumption of acetate under different agar granule size in immobilized photo-hydrogen production. inoculant age of the immobilized bacteria is the key factor affecting hydrogen production, $R$. rubrum of inoculant age of $70 \mathrm{~h}$ were immobilized with the highest hydrogen production activity [18]. Therefore, inoculant age of about $24 \mathrm{~h}$ and $72 \mathrm{~h}$ for photo-hydrogen production is appropriate.

\subsection{The Effect of Agar Concentration}

Photo-hydrogen production significantly influenced by agar concentration, which directly determined the absorbance of photo-fermentative bacteria, utilization efficiency and transfer rates of substrate.

Agar concentration was in the range of $1 \%-4 \%$, agar gel granule size of $2.5 \mathrm{~mm}$ and inoculant age of $24 \mathrm{~h}$ were used in this test. When agar concentration was $1.5 \%$ and $2 \%$, cumulative volume of hydrogen was 254.98 $\mathrm{ml} /$ reactor and $249.67 \mathrm{ml} /$ reactor, hydrogen production capacity was higher than that of other agar concentration (Figure 4). The performance of hydrogen production was similar to the control under agar concentration of $1 \%$, $3 \%$ and $4 \%$. Agar concentration over 3\%, penetration of light into inside bacterial cell decreased and the growth rate will be decreased with increasing the agar concentration, thereby affecting the utilization of its substrate and the internal mass transfer resistance increased. This result was similar to Seol. et al.'s research, which indicated that the substrate and products are easily transferred through the bead when agar concentration in proper experimental ranges [19]. In addition, the accumulation of cell metabolite in the agar granule caused cell toxicity and repressed infiltration capacity of substrate, will also affect the growth and hydrogen production of photo-fermentation bacteria.

\subsection{The Effect of Bacterial Concentration in Agar Gel}

The bacterial concentration in agar influenced utilization and mass transfer efficiency of substrate. Biomass in agar was $2,4,6,8$ and $10 \mathrm{mg} / \mathrm{ml}$, respectively. Agar gel granule size, inoculant age, agar concentration, acetate concentration and reaction system were $3 \mathrm{~mm}, 24 \mathrm{~h}, 2 \%, 50$ $\mathrm{mmol} / \mathrm{l}$ and $80 \mathrm{ml}$, respectively.

Result indicated the biomass range of $2-4 \mathrm{mg} / \mathrm{ml}$ in agar may help to improve performance of hydrogen production and hydrogen yield decreased when biomass was over $6 \mathrm{mg} / \mathrm{ml}$; high biomass in gel granule for enhancing the hydrogen production is not obvious (Figure 5). Reason may be due to the substrate into the gel granules was constant and excessive photo-fermentation bacteria were employed in hydrogen production process leading to the consumption of a lot of substrate to maintain the energy require for their growth, thus reducing the use of substrate for hydrogen production and immobilized cells 


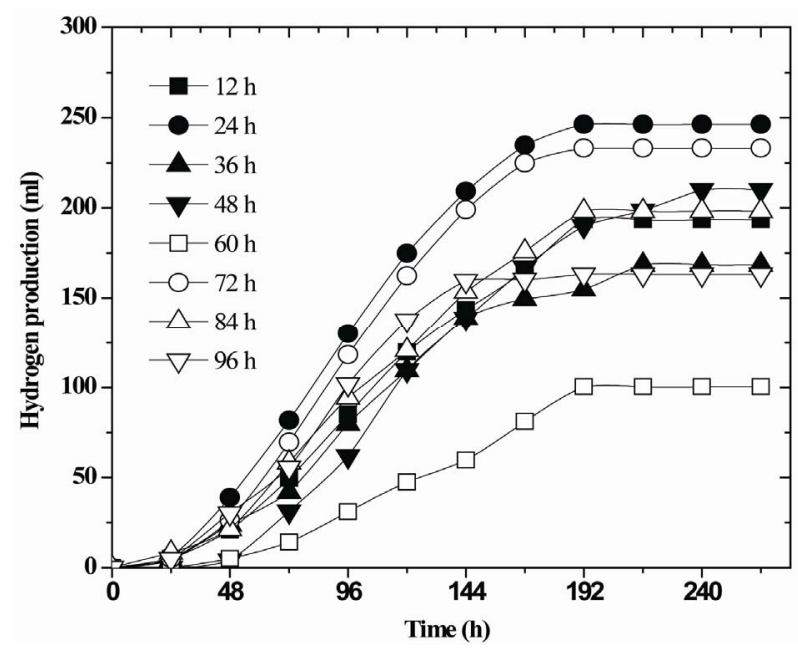

Figure 3. The effect of inoculant age on photo- $\mathrm{H}_{2}$ production.

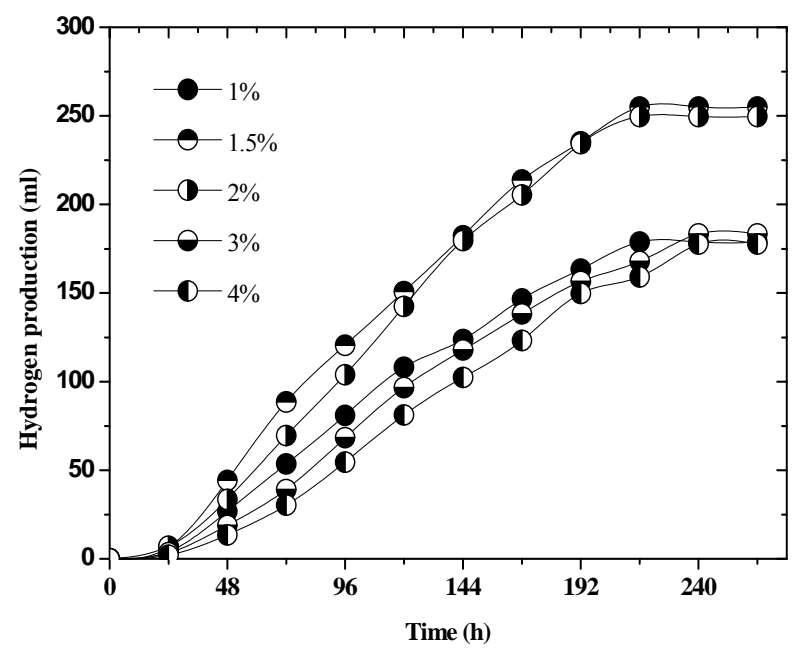

Figure 4. The effect of agar concentration on photo- $\mathrm{H}_{2}$ production.

activity was prevented. So, the biomass of a certain concentration range can promote hydrogen production capacity of immobilized photo-fermentation bacteria. However, the biomass in gel granule is too high and substrate to maintain bacterial physical requirement exceeded, thereby the hydrogen production capacity reduced. The suitable cell concentration of $1 \mathrm{mg} / \mathrm{ml}$ not only achieved the highest hydrogen yield but also more important superior nitrogenase activity [18].

\subsection{PH Tolerant Capacity}

To determine acids tolerance of immobilized cell, in this test, the $\mathrm{pH}$ of reaction system was adjusted to 4.0, 5.0, $5.5,6.0$ and 6.5, respectively. Agar granule diameter of $2.5 \mathrm{~mm}$, inoculum age of $24 \mathrm{~h}$, agar concentration of $2 \%$, biomass of $4 \mathrm{mg} / \mathrm{ml}$ in agar and acetate of $50 \mathrm{~m} \mathrm{~mol} / \mathrm{l}$

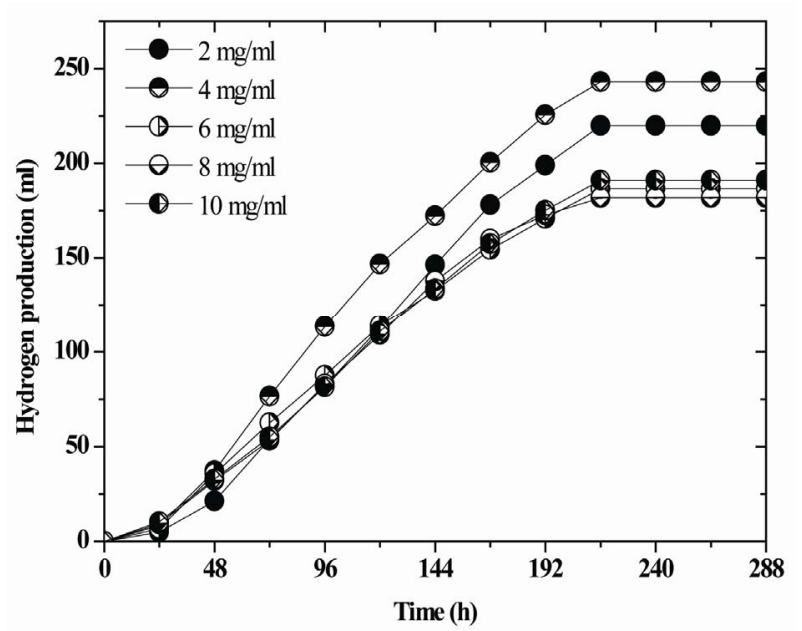

Figure 5. The effect of biomass concentration in agar gel granule.

were constant in $80 \mathrm{ml}$ system.

A decrease in $\mathrm{pH}$ resulting in decrease in the yield and production rate of hydrogen (Figure 6). In all $\mathrm{pH}$ tests, compared to initial $\mathrm{pH}$, final $\mathrm{pH}$ increased slightly due to the consumption of acetate (Figure 7). At low $\mathrm{pH} 4.0$, bacteria can not grow and hydrogen also not produced. Little hydrogen was generated and cumulative hydrogen volume only was $50 \mathrm{ml}$ at $\mathrm{pH} 5.0$. The lag time of hydrogen production was about $72 \mathrm{~h}$ and hydrogen produc-

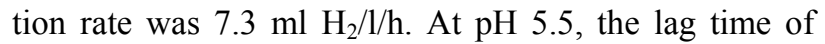
hydrogen production decreased to about $48 \mathrm{~h}$ and hydrogen production yield and rate started to increase. Cumulative hydrogen volume and maximum hydrogen production rate reached $149 \mathrm{ml}$ and $17.7 \mathrm{ml} \mathrm{H}_{2} / \mathrm{l} / \mathrm{h}$, respectively. At $\mathrm{pH} 6.0$ and 6.5, the trend of hydrogen production was similarly within $144 \mathrm{~h}$. After $144 \mathrm{~h}$, hydrogen production rate increased slightly under $\mathrm{pH}$ 6.5. Finally, maximum

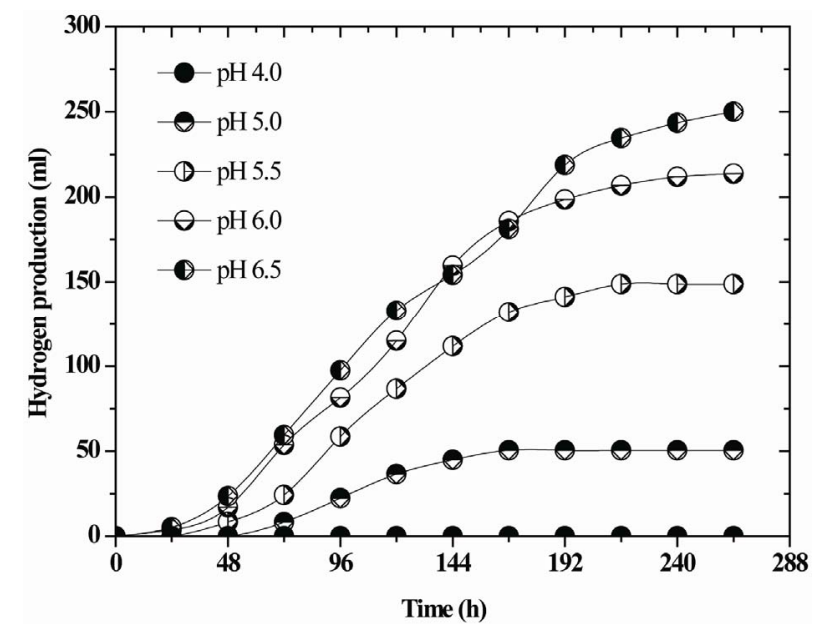

Figure 6. Acid-tolerance capacity of strain RLD-53 during $\mathrm{H}_{2}$ Production. 


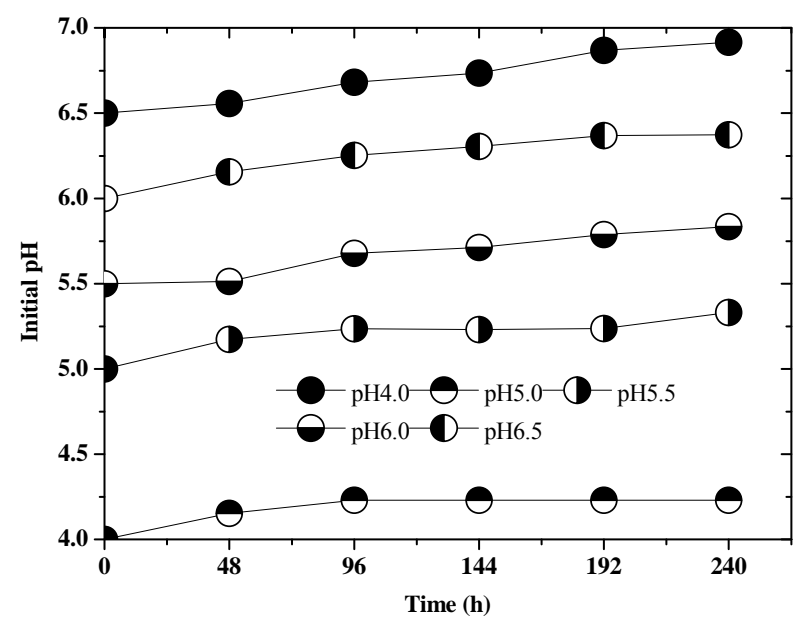

Figure 7. The change of $\mathrm{pH}$ under different initial pH during entire $\mathrm{H}_{2}$ production.

hydrogen yield of $250 \mathrm{ml}$ and rate of $23.4 \mathrm{ml} \mathrm{H} / \mathrm{l} / \mathrm{h}$ was obtained at $\mathrm{pH}$ 6.5. Suitable range of $\mathrm{pH}$ is at $6.5-7.5$ for non-immobilized photo-fermentation bacteria $[16,20]$. Thereby, above results implied that $\mathrm{pH}$ are an important factors for sustained and efficient hydrogen production in immobilized strain RLD-53 and the immobilized fermentation bacteria have certain acids-tolerance capacity with high hydrogen yield. Immobilized photo-fermentative bacteria can tolerate lower $\mathrm{pH}$ of a certain extent, even at $\mathrm{pH} 5.0$ hydrogen also was produced.

\subsection{Requirement of Light Intensity}

The growth and hydrogen production of photo-fermentation bacteria need to apply energy by light condition. So, light intensity also was an important limiting factor for photo-hydrogen production. The optimum light intensity of non-immobilized strain RLD-53 for hydrogen production was at 3000-5000 lux [16], and the bacteria were immobilized on agar, which can prevent the infiltration of light and light absorption of bacteria. Therefore, the investigation of light intensity of immobilized bacteria is necessary.

Effect of different light intensities on the hydrogen production is depicted in Figure 8. It has been observed that increased light intensity resulted in an increase in the total volume of hydrogen and also hydrogen production rate. The lower light intensity accompanied a long lag time of hydrogen production. Light intensity was at 1000 lux, lag time of hydrogen production is $48 \mathrm{~h}$ and the lowest yield of hydrogen of $178 \mathrm{ml}-\mathrm{H}_{2} /$ reactor was obtained. When the light intensity was at 7000 lux and 9000 lux, the hydrogen production capacity was closed, the cumulative volume of hydrogen gas were $246 \mathrm{ml}-\mathrm{H}_{2} /$ reactor and $255 \mathrm{ml}-\mathrm{H}_{2} /$ reactor, respectively, the maximum hydrogen production rate reached $24 \mathrm{ml}-\mathrm{H}_{2} / \mathrm{l} / \mathrm{h}$. It can be

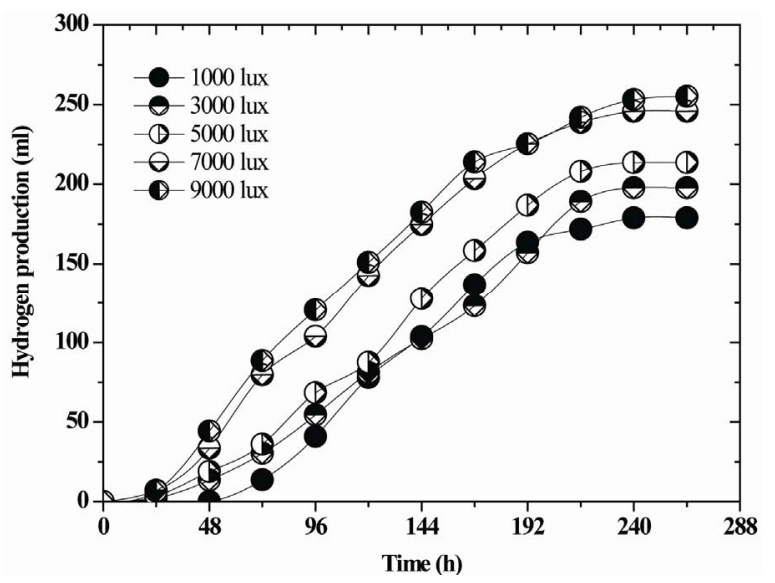

Figure 8. The effect of light intensity on photo- $\mathrm{H}_{2}$ production.

observed that the hydrogen production under highest light intensity reached a higher yield. Usually, high light intensity can inhibit hydrogen production by non-immobilized photo-fermentation bacteria [16, 21]. However, these results indicated that the range of optimal light intensity for hydrogen production by immobilized phorofermentation bacteria was between 7000 - 9000 lux. This also suggested that the phoro-fer-mentation bacteria immobilized in agar to prevent the light penetration into inside bacterial cells and light absorption of the bacterial photosynthetic system, further influence generation of electronic and synthesis of ATP, leading to bacterial growth, nitrogenase activity and hydrogen production were inhibited. Therefore, light intensity needs to increase to obtain enough supply of light energy for the growth and producing hydrogen of photo-fermentation bacteria.

\section{Conclusions}

Results obtained in this study clearly exhibited the immobilized photo-fermentation bacteria could obviously promote hydrogen production, the conversion efficiency of substrate and lengthen time of hydrogen production. More importantly, it demonstrated that the granule diameter, inoculant age, agar concentration, biomass in agar and light intensity are key factors affecting photofermentation hydrogen production, and when they are 2.5 $\mathrm{mm}, 24$ or $72 \mathrm{~h}, 2 \%, 4 \mathrm{mg} / \mathrm{ml}$ and $7000-9000$ lux, the maximum hydrogen yield reached $3.15 \mathrm{~mol}-\mathrm{H}_{2} /$ molacetate. The immobilized photo fermentation bacteria not only can enhance hydrogen production but can increase acids-tolerance capacity, even at $\mathrm{pH} 5.0$ hydrogen also was produced, and thus hopefully immobilized photo-fermentation bacteria can be applied in the combination of dark and photo-fermentation for hydrogen production with high yield. 


\section{Acknowledgements}

This research was supported by the financial support from the National Nature Science Foundation of China (No. 30870037, 50821002 and 50638020), State Key Laboratory of Urban Water Resource and Environment (HIT) (Grant No.QAK200806). The authors would like to thank the Key Laboratory of water/soil toxic pollutants control and bioremediation of Guangdong Higher Education Institutes, Jinan University for supporting this study.

\section{REFERENCES}

[1] P. C. Hallenbeck, "Fermentative Hydrogen Production: Principles, Progress and Prognosis," International Journal of Hydrogen Energy, Vol. 34, No. 17, 2009, pp. 7379-7389. doi:10.1016/i.ijhydene.2008.12.080

[2] E. Ozgür, A. E. Mars, B. Peksel, A. Louwerse, M. Yücel, U. Gündüz, P. A. M. Claassen and I. Eroglu, "Biohydrogen Production from Beet Molasses by Sequential Dark and Photo-Fermentation," International Journal of Hydrogen Energy, Vol. 35, No. 2, 2010, pp. 511-517. doi:10.1016/j.ijhydene.2009.10.094

[3] B. F. Liu, N. Q. Ren, D. F. Xing, J. Ding, G. X. Zheng, W. Q. Guo, J. F. Xu and G. J. Xie, "Hydrogen Production by Immobilized $R$. faecalis RLD-53 Using Soluble Metabolites from Ethanol Fermentation Bacteria E. Harbinense B49," Bioresource Technology, Vol. 100, No. 10, 2009, pp. 2719-2723. doi:10.1016/j.biortech.2008.12.020PMid:19200719

[4] B. F. Liu, N. Q. Ren, G. J. Xie, J. Ding, W. Q. Guo and D. F. Xing, "Enhanced Bio-Hydrogen Production by the Combination of Dark and Photo Fermentation in Batch Culture," Bioresource Technology, Vol. 101, No. 14, 2010, pp. 5325-5329. doi:10.1016/j.biortech.2010.02.024

[5] S. Ozmihci and F. Kargi, "Bio-Hydrogen Production by Photo-Fermentation of Park Fermentation Effluent with Intermittent Feeding and Effluent Removal," International Journal of Hydrogen Energy, Vol. 35, No. 13, 2010, pp. 6674-6680. doi:10.1016/j.ijhydene.2010.04.090

[6] H. Argun and F. Kargi, "Effects of Light Source, Intensity and Lighting Regime on Bio-Hydrogen Production from Ground Wheat Starch by Combined Dark and Photo-Fermentations," International Journal of Hydrogen Energy, Vol. 35, No. 4, 2010, pp. 1604-1612. doi:10.1016/j.ijhydene.2009.12.033

[7] Y. C. Lo, C. Y. Chen, C. M. Lee and J. S. Chang, "Sequential Dark-Photo Fermentation and Autotrophic Microalgal Growth for High-Yield and $\mathrm{CO}_{2}$-free BioHydrogen Production," International Journal of Hydrogen Energy, Vol. 35, No. 20, 2010, pp.10944-10953. doi:10.1016/j.ijhydene.2010.07.090

[8] B. Uyar, I. Eroglu, M. Yücel and U. Gündüz, "Photo Fermentative Hydrogen Production from Volatile Fatty Acids Present in Dark Fermentation Effluents," International Journal of Hydrogen Energy, Vol. 34, No. 10, 2009, pp. 4517-4523.

doi:10.1016/j.ijhydene.2008.07.057
[9] S. K. S. Patel, H. J. Purohit and V. C. Kalia, "Dark Fermentative Hydrogen Production by Defined Mixed Microbial Cultures Immobilized on Ligno-Cellulosic Waste Materials," International Journal of Hydrogen Energy, Vol. 35, No. 19, 2010, pp. 10674-10681. doi:10.1016/j.ijhydene.2010.03.025

[10] J. H. Jo, D. S. Lee, D. Park and J. M. Park, "Biological Hydrogen Production by Immobilized Cells of Clostridium Tyrobutyricum JM1 Isolated from a Food Waste Treatment Process," Bioresource Technology, Vol. 35, No. 19, 2008, pp. 6666-6672. doi:10.1016/j.biortech.2007.11.067

[11] T. Matsunaga, I, Karube and S. Suzuki, "Some Observations on Immobilized Hydrogen-Producing Bacteria: Behavior of Hydrogen in Gel Membranes," Biotechnology Bioengineering, Vol. 22, No. 12, 1980, pp. 2607-2615. doi:10.1002/bit.260221209

[12] J. O. Kim, Y. H. Kim, J. Y. Ryu, B. K. Song, I. H. Kim and S. H. Yeom, "Immobilization Methods for Continuous Hydrogen Gas Production Biofilm Formation Versus Granulation," Process Biochemistry, Vol. 40, No. 3-4, 2005, pp. 1331-1337. doi:10.1016/j.procbio.2004.06.008

[13] H. Yokoi, T. Tokushige, J. Hirose, S. Hayashi and Y. Takasaki, "Hydrogen Production by Immobilized Cells of Aciduric Enterobacter Aerogenes Strain HO-39," Journal of Fermentation and Bioengineering, Vol. 83, No. 5, 1997, pp. 481-484. doi:10.1016/S0922-338X(97)83006-1

[14] S. Sawayama, K. K. Rao and D. Hall, "Immobilization of Rhodobacter capsulatus on Cellulose Beads and Water Treatment Using a Photobioreactor," Journal of Fermentation and Bioengineering, Vol. 86, No. 5, 1998, pp. 517-520. doi:10.1016/S0922-338X(98)80164-5

[15] X. Tian, Q. Liao, W. Liu, Y. Z. Wang, X. Zhu, J. Li and H. Wang, "Photo-Hydrogen Production Rate of A PVA-Boric Acid Gel Granule Containing Immobilized Photosynthetic Bacteria Cells," International Journal of Hydrogen Energy, Vol. 34, No. 11, 2009, pp. 4708-4717. doi:10.1016/j.ijhydene.2009.03.042

[16] N. Q. Ren, B. F. Liu, J. Ding and G. J. Xie, "Hydrogen Production with $R$. faecalis RLD-53 Isolated from Freshwater Pond Sludge," Bioresource Technology, Vol. 100, No. 1, 2009, pp. 484-487. doi:10.1016/j.biortech.2008.05.009

[17] B. F. Liu, N. Q. Ren, J. Ding, G. J. Xie and W. Q. Guo, "The Effect of $\mathrm{Ni}^{2+}, \mathrm{Fe}^{2+}$ and $\mathrm{Mg}^{2+}$ Concentration on Photo-Hydrogen Production by Rhodopseudomonas faecalis RLD-53," International Journal of Hydrogen Energy, Vol. 34, No. 2, 2009, pp. 721-726. doi:10.1016/j.ijhydene.2008.11.033

[18] P. Felten, H. Zürrer and R. Bachofen, "Production of Molecular Hydrogen with Immobilized Cells of Rhodospirillum rubrum," Applied Microbiology and Biotechnology, Vol. 23, No 1, 1985, pp. 15-20. doi:10.1007/BF02660112

[19] E. Seol, A. Manimaran, Y. Jang, S. Kim, Y. K. Oh and S. Park, "Sustained Hydrogen Production from Formate Using Immobilized Recombinant Escherichia coli SH5," International Journal of Hydrogen Energy (in Press). 
doi:10.1016/j.ijhydene.2010.05.118

[20] R. Merugu, S. Girisham and S. M. Reddy, "Bioproduction of Hydrogen by Rhodobacter capsulatus KU002 Isolated from Leather Industry Effluents," International Journal of Hydrogen Energy, Vol. 35, No. 18, 2010, pp. 9591-9597. doi:10.1016/j.ijhydene.2010.06.057

[21] H. Argun and F. Kargi, "Effects of Light Source, Inten- sity and Lighting Regime on Bio-hydrogen Production from Ground Wheat Starch by Combined Dark and Photo-Fermentations," International Journal of Hydrogen Energy, Vol. 35, No. 4, 2010, pp. 1604-1612. doi:10.1016/i.ijhydene.2009.12.033 